\title{
Pengembangan Bahan Ajar Materi Prisma Berbasis Android untuk Pembelajaran Berbasis Masalah di Kelas VIII
}

\author{
Mitha Frilia Hidayat ${ }^{*}$, Hapizah ${ }^{2}$, Ely Susanti ${ }^{3}$, Scristia $^{4}$ \\ ${ }^{1234}$ Universitas Sriwijaya, Palembang, Provinsi Sumatera Selatan, Indonesia
}

Pengiriman: 27/Juni/2020; Diterima: 23/September/2020; Publikasi: 30/September/2020

DOI: https://doi.org/10.31629/jg.v5i2.2362

\begin{abstract}
Abstrak
Perkembangan teknologi di era industri 4.0 membuat perubahan pada sistem pendidikan. Sistem pendidikan telah berubah menjadi lebih modern dengan penggunaan teknologi yang dipakai pada proses pembelajaran. Penelitian pengembangan ini bertujuan untuk menghasilkan bahan ajar yang valid dan praktis untuk pembelajaran berbasis masalah dikelas VIII dengan objek penelitiannya ialah bahan ajar berbasis android. Desain penelitian yang digunakan adalah model pengembangan ADDIE meliputi (1) analisis, (2) desain dan (3) pengembangan. Pengumpulan data menggunakan lembar validasi, observasi dan angket. Kelayakan bahan ajar ditentukan oleh ahli materi dan ahli media. Data hasil penelitian ini dianalisis dengan menggunakan metode deskriptif kuantitatif. Hasil penelitian menunjukkan bahwa bahan ajar sudah valid dilihat dari hasil validasi dan one-to-one sedangkan kepraktisan pada bahan ajar dilihat dari hasil data observasi dan angket, pada hasil data observasi didapatlah ratarata $86 \%$ yang terkategori sangat praktis dan pada hasil data angket didapatlah rata-rata $86,33 \%$ yang terkategori sangat praktis sehingga dapat disimpulkan bahwa bahan ajar berbasis android pada materi prisma untuk pembelajaran berbasis masalah dikelas VIII sudah dikategorikan valid dan praktis.
\end{abstract}

Kata kunci: pengembangan; bahan ajar; android; prisma

\begin{abstract}
Technological developments in the industrial era 4.0 made changes to the education system. The education system must change to become more modern with the use of technology used in the learning process. This development research aims to make valid and practical teaching materials for problem-based learning in class VIII with the object of research is Android-based teaching materials. The research design is the ADDIE development model with 3 stages of development including (1) analysis, (2) design and (3) development. Data collection uses validation, observation and questionnaire sheets. Teaching materials are determined by material experts and media experts. Data from the results of this study were analyzed using quantitative descriptive methods. The results showed the teaching material was valid seen from the results of validation and one-to-one while the practicality of teaching material was seen from the results of observational data and questionnaires, the results of observational data obtained an average of $86 \%$ categorized as very practical and on the results of the questionnaire data obtained an average of $86.33 \%$ categorized as very practical so it can be concluded that the android-based teaching material on prism material for problem-based learning in class VIII has been categorized as valid and practical.
\end{abstract}

Keywords: development; teaching materials; android; prism

*Penulis Korespondensi

Email Address: friliamitha@gmail.com

Handphone : :+6289622320789 


\section{JURNAL GANTANG. September 2020; V(2): 191 - 201 \\ p-ISSN. 2503-0671 \\ e-ISSN. 2548-5547}

\section{Pendahuluan}

Prisma merupakan salah satu materi pada mata pelajaran matematika di Sekolah Menengah Pertama yang masuk dalam sub bab bangun ruang sisi datar, materi prisma sangat penting dipahami oleh siswa karena materi tersebut masuk ke dalam kisi-kisi Ujian Sekolah Berstandar Nasional (USBN) dan Ujian Nasional (Kemendikbud,2019). Namun, pentingnya materi prisma tidaklah sejalan dengan fakta yang ditemui di sekolah, materi bangun ruang masih banyak membuat siswa bingung padahal materi ini sudah pernah dipelajari di Sekolah Dasar dan hampir semua objek visual yang ada disekitar siswa merupakan bentuk dari bangun ruang (Yetizon, 2020). Nyatanya materi bangun ruang masih saja membuat siswa kesulitan dalam menyelesaikan permasalahan-permasalahan yang diberikan oleh guru. Kesulitan yang dialami oleh siswa karena siswa tidak tahu harus memakai rumus yang mana, siswa hanya menghafal saja rumus yang diberikan oleh guru tanpa memahami dari mana rumus itu didapatkan sehingga proses belajar siswa menjadi tidak bermakna (Sondek, 2016).

Kesulitan siswa ini akan menimbulkan rasa malas terhadap materi pelajaran yang diajarkan oleh guru dan ini akan berakibat pada keberhasilan siswa dalam memahami pelajaran, jika siswa tidak berhasil dalam proses belajar dikelas maka ini menjadi tanda tanya besar apakah ada masalah dalam proses pembelajarannya (Prisiska et al, 2017). Adapun faktor lain yang menyebabkan siswa menjadi malas belajar ialah guru hanya menjelaskan materi prisma kepada siswa dengan menggunakan buku teks biasa karena rata-rata guru yang ada di Indonesia masih menggunakan buku teks biasa dalam mengajar di kelas (Kasmawati, 2017). Apabila dikaitkan dengan materi prisma yang merupakan materi bangun ruang tiga dimensi, tentunya membutuhkan visualisasi yang jelas tidak seperti buku teks biasa yang hanya dua dimensi sehingga tidak dapat menggambarkan dengan jelas bentuk dari bangun ruang tersebut (Hardiyanti, 2018). Selain itu menurut pendapat dari Muyaroah \& Fajartia (2018) kurangnya pemanfaatan sarana dan prasarana terutama dalam bidang teknologi yang berkembang saat ini. Padahal jika mengikuti perkembangan teknologi yang ada buku teks biasa dapat diubah menjadi suatu bahan ajar yang menarik dan inovatif. Oleh karena itu, dibutuhkannya suatu bahan ajar yang bisa membuat siswa menjadi tertarik dalam proses belajar serta dapat membantu siswa dalam memahami materi yang diajarkan oleh guru dan membuat pembelajaran menjadi lebih bermakna khususnya pada materi tiga dimensi yaitu prisma.

Bahan ajar merupakan segala informasi dalam bentuk teks, visual, audio ataupun gabungan dari ketiganya yang dibutuhkan oleh siswa untuk dipelajari, guna mencapai kompetensi secara utuh dan terpadu. Inovasi yang telah dilakukan dalam dunia pendidikan ialah membuat bahan ajar yang interaktif, yang mana bahan ajar tersebut merupakan bahan ajar yang mengkombinasikan dua atau lebih media seperti audio, teks, grafik, gambar maupun animasi (Manasikana, 2017). Inovasi tersebut sejalan dengan perkembangan teknologi di era industri 4.0 yang sangat berpengaruh terhadap pendidikan yang ada di Indonesia, dimana pendidikan pada era 4.0 ini bercirikan dengan adanya penggunaan teknologi digital dalam proses pembelajaran yang ada di sekolah (Sunarto, 2015).

Sesuai dengan kurikulum 2013 yang menuntut pembelajaran menggunakan IT, dengan adanya penggunaan IT dalam proses pembelajaran ini dapat membuat siswa belajar tanpa terbatas oleh ruang dan waktu (Wijayanto, 2018). Teknologi yang telah berkembang ini memunginkan sebuah bahan ajar dikemas menjadi lebih menarik dan praktis. Salah satu perangkat yang dapat dimanfaatkan di dunia pendidikan saat ini ialah handphone. Dewasa ini, handphone sudah menjadi kebutuhan bagi seluruh lapisan masyarakat baik dari anak kecil hingga orang dewasa. Saat ini banyak handphone yang beredar di masyarakat yaitu handphone 
pintar (smartphone) yang dikenal dengan android (Jazuli et al, 2017). Penggunaan android merupakan cara alternatif dalam proses pembelajaran karena siswa bisa belajar kapan saja dan dimana saja. Selain itu penggunaan android dapat meningkatan kualitas dalam proses belajar karena android dapat didesain sebagai sarana untuk mencapai tujuan pembelajaran yang diinginkan (Purnama et al, 2017).

Untuk dapat meningkatkan pemahaman siswa dengan bahan ajar yang sudah dikembangkan, perlu adanya suatu model pembelajaran yang bisa membuat siswa menjadi lebih aktif dalam proses pembelajarannya. Model pembelajaran yang memperhatikan kebermaknaan belajar dan pengalaman siswa dalam kelas sehingga siswa menjadi paham akan konsep dari materi yang diajarkan oleh guru ialah model pembelajaran berbasis masalah (Allo et al, 2019). Model pembelajaran berbasis masalah merupakan suatu model pembelajaran yang menggunakan masalah nyata sebagai konteksnya, disini siswa akan mencoba mencari penyelesaian dari permasalahan yang diberikan sehingga menuntut siswa berpikir kritis dalam memecahkan masalah yang diberikan oleh guru (Mahmidatul, 2020). Pada model pembelajaran tersebut, siswalah yang menjadi pusat dalam proses belajar, sedangkan guru hanya sebagai fasilitator di kelas. Hal ini akan membuat siswa menjadi tertarik dan termotivasi dalam menyelesaikan soal yang diberikan sebab permasalahan yang diberikan adalah permasalahan yang nyata sehingga membutuhkan penyelesaian yang nyata pula (Wahyuni, 2018). Model pembelajaran berbasis masalah ini bertujuan untuk menyusun pengetahuan siswa, melatih kemandirian dan rasa percaya diri serta mengembangkan keterampilan dalam pemecahan masalah.

Model pembelajaran berbasis masalah memiliki lima langkah yang menjadi ciri model ini yaitu: 1) orientasi siswa kepada masalah, 2) mengorganisasikan siswa, 3) membimbing penyelidikan individu dan kelompok, 4) mengembangkan dan menyajikan hasil karya, 5) menganalisis dan mengevaluasi pemecahan masalah. Dalam pendekatan ini guru haruslah kreatif untuk memberikan permasalah yang nyata, dan memberikan bahan ajar serta fasilitas yang diperlukan siswa untuk memecahkan masalah (Prisiska et al, 2017). Model pembelajaran ini berkaitan dengan pengetahuan prosedural yang terstruktur yang dapat diajarkan dengan pola kegiatan yang bertahap, jadi siswa disini akan dibimbing untuk memahami konsep dari materi yang diajarkan itu secara bertahap.

Berdasarkan uraian diatas, peneliti tertarik untuk mengadakan penelitian dengan judul, "Pengembangan Bahan Ajar Materi Prisma Berbasis Android untuk Pembelajaran Berbasis Masalah di Kelas VIII". Adapun tujuan daripada penelitian ini yaitu untuk menghasilkan bahan ajar materi prisma berbasis android untuk pembelajaran berbasis masalah yang valid dan praktis dan hasil dari penelitian tersebut ialah berupa aplikasi yang bisa digunakan siswa untuk pembelajaran di kelas khususnya pada materi bangun ruang sisi datar yaitu prisma, dengan adanya aplikasi ini diharapkan dapat membuat siswa menjadi lebih paham dengan bantuan dari bentuk tiga dimensi yang ditampilkan dalam aplikasi yang berupa video pembelajaran yang menarik dan mudah dipahami. Sehingga, dapat memudahkan guru dalam mengajar di kelas dan membuat siswa paham dengan bentuk nyata dari prisma.

\section{Metode Penelitian}

Penelitian ini menggunakan model pengembangan ADDIE yang mana menurut Wijani (2013 : 42) model ADDIE bertujuan untuk menghasilkan suatu produk yang efektif dan mampu meningkatkan kualitas belajar siswa dikelas, adapun pada penelitian ini tujuan dari penggunaan model ADDIE ialah untuk menghasilkan suatu produk berupa bahan ajar materi prisma yang berbasis android untuk pembelajaran berbasis masalah yang valid dan praktis. Objek dalam penelitian tersebut adalah bahan ajar berbasis android, sedangkan subjeknya yaitu siswa-siswa SMP Negeri 10 
JURNAL GANTANG. September 2020; V(2): 191 - 201

p-ISSN. 2503-0671

e-ISSN. 2548-5547

Palembang, Sumatera Selatan. Alur tahapan pengembangan model ADDIE Langkah-langkah pada alur desain tersebut dapat dijelaskan sebagai berikut:

\section{Tahap Analisis (Analysis)}

Tahap analisis ini proses mendefinisikan apa yang akan dipelajari oleh peserta didik. Tahapannya sebagai berikut:

a. Analisis Kebutuhan

Pada analisis kebutuhan, yang dilakukan ialah menganalisis ketersediaan dari bahan ajar yang dibutuhkan untuk mendukung proses pembelajaran.

b. Analisis Kurikulum

Pada analisis kurikulum, materi pelajaran yang dianalisis pada penelitian ini ialah materi prisma pada sub bab bangun ruang sisi datar di kelas VIII pada kurikulum 2013.

c. Analisis Karakteristik Siswa

Pada analisis karakteristik, yang dilakukan ialah menganalisis sikap siswa terhadap pelajaran matematika. Sikap ini bisa terlihat pada saat proses pembelajaran dikelas dengan menggunakan instrumen berupa lembar observasi yang telah dibuat oleh peneliti.

\section{Tahap Desain (Design)}

Tahap design terdiri dari merancang masalah yang ingin ditampilkan, pembuatan storyboard yang berisi rancangan tampilan awal aplikasi serta alur penggunaannya.

\section{Tahap Pengembangan (Development)}

Pengembangan produk bahan ajar berbasis android menggunakan software Android Studio berdasarkan tahap-tahap berikut:

a.Peneliti menggabungkan bahan-bahan yang sudah terkumpul

b.Membuat lembar validasi

c.Meminimalisir kelemahan yang ada lalu direvisi

\section{Metode Pengumpulan Data}

Adapun langkah-langkah pengumpulan data dari penelitian ini ialah walk through, observasi dan angket.

\section{Walk Through}

Walk Through digunakan untuk memperoleh data validasi dari para ahli dan dari siswa

\section{Observasi}

Observasi digunakan untuk mengetahui kepraktisan ataupun kelayakan dari produk yang telah dikembangkan oleh peneliti.

3. Angket

Lembar angket yang dibuat berpacu pada indikator-indikator yang dilihat yaitu pernyataan positif maupun pernyataan negatif

\section{Metode Analisis Data}

Data yang sudah di kumpulkan akan dilakukan analisis oleh peneliti, analisis data yang dilakukan oleh peneliti sebagai berikut:

1. Analisis Data Walkthrough

Berdasarkan walk through yang dilakukan oleh validator, data ini kemudian dianalisis secara deskriptif kualitatif oleh peneliti.

2. Analisis Data Observasi

Analisis data observasi yaitu untuk melihat kepraktisan bahan ajar, berpacu pada tabel skala likert.

3. Analisis Data Angket

Data yang terkumpul dari angket ini akan dilakukan analisis dengan perhitungan skala likert dilihat dari pernyataan posistif dan negatifnya.

\section{Hasil dan Pembahasan}

Berdasarkan pada tahapan pengembangan dengan model ADDIE, maka penelitian ini melalui beberapa tahapan yaitu: tahap analisis (analysis), desain (design), pengembangan (development), implementasi (implementation) dan evaluasi (evaluation). Pada penelitian ini, hanya sampai pada tahap pengembangan dengan uji coba small grup tidak sampai pada implementasi dan evaluasi karena penelitian ini hanya mengembangkan bahan ajar untuk dilihat kepraktisannya bukan keefektikannya.

Pada tahap analisis, peneliti melakukan analisis terhadap kebutuhan, kurikulum dan karakteristik. Berdasarkan analisis kebutuhan diperolelah informasi mengenai ketersediaan dari smartphone yang berbasiskan android di sekolah, kemampuann dalam mengoperasikan smarthphone. Namun ketersediaan smartphone tersebut tidak di gunakan dengan bijak dan 
maksimal, kebanyakan siswa menggunakan smartphone untuk melakukan hal-hal yang tidak bermanfaat dalam waktu yang lama dibandingkan belajar dengan alasan belajar itu membosankan sehingga sangat memungkinkan untuk mengembangkan suatu inovasi baru yaitu bahan ajar yang berbasiskan android pada proses belajar di sekolah. Sehingga dapat meminimalisir penggunaan smartphone untuk hal-hal yang tidak bermanfaat. Sedangkan hasil dari analisis kurikulum peneliti memilih KD 3.9 dan 4.9 yaitu tentang luas permukaan dan volume bangun ruang prisma, namun pada penelitian ini peneliti membatasi materi yang ada dalam bahan ajar.

Materi yang ada dalam bahan ajar tersebut hanya luas permukaan prisma yang mencakup pengertian, jaring-jaring, contoh, dan rumus. Kemudian peneliti menentukan indikatorindikator yang akan dicapai setelah menggunakan bahan ajar tersebut. Adapun hasil dari analisis karakteristik siswa yaitu masih terlihat bahwa matematika masih menjadi suatu pelajaran yang dianggap membosankan oleh siswa. Sehingga perlu adanya suasana baru dan proses pembelajaran yang menarik perhatian siswa untuk belajar matematika, yaitu bisa dengan bahan ajar yang berbeda dari sebelumnya. Bahan ajar berbasiskan android dapat membantu siswa agar lebih tertarik dengan pelajaran matematika, karena bahan ajar ini dilengkapi dengan video pembelajaran yang digabungkan dengan animasi-animasi yang menarik.

Pada tahap desain peneliti menyiapkan isi yang ada dalam bahan ajar. Isi tampilan pada bahan ajar tersebut sesuai dengan komponen dari bahan ajar yaitu (1) petunjuk belajar, (2) KI, KD dan indikator, (3) permasalahan (diberikan tayangan berupa video dan diakhir video akan diberikan suatu pertanyaan yang berkaitan dengan luas permukaan prisma) (4) materi (mencakup pengertian prisma, jaring-jaring prisma, contoh prisma dan rumus prisma) dan yang terakhir (5) evaluasi (berisikan soal-soal yang berkaitan dengan materi prisma). Komponen dari bahan ajar ini sesuai dengan langkah-langkah dari model pembelajaran berbasis masalah yaitu dimulai dari memberikan suatu masalah yang dibuat oleh peneliti, kemudian siswa digiring untuk menemukan pemahaman dari mana rumus luas permukaan prisma itu berasal lalu baru masuk kepada materi prisma yang berupa rangkuman dari buku dan sumber lainnya serta yang terakhir siswa diberikan soal evaluasi sesuai dengan tahap akhir dari model pembelajaran berbasis masalah yaitu melakukan evaluasi terhadap pelajaran yang diberikan.

Tahap selanjutnya membuat storyboard kegunaan dari storyboard yaitu untuk mengambarkan tampilan secara garis besar dari tiap layout yang ada. Pada pembuatan storyboard ini untuk desain awal menggunakan aplikasi Power Point 2010 dengan memperhatikan tata letak dari tiap button maupun tampilan pada bahan ajar yang dikembangkan. Hasil rancangan storyboard pada bahan ajar berbasiskan android diperlihatkan pada Gambar 1.

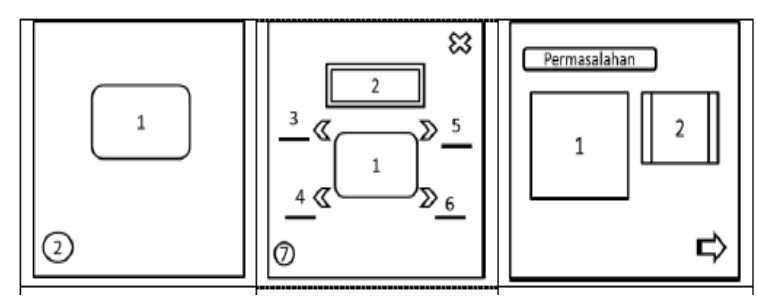

Gambar 1 Storyboard tampilan aplikasi

Gambar 1 memperlihatkan storyboard dari tampilan awal bahan ajar pada saat pertama kali aplikasi dibuka adapun penjelasannya yaitu gambar logo (No.1) dari materi yang dipelajari yaitu tentang materi prisma dan (No. 2) berisikan tentang aplikasi mencakup kompetensi dasar, pembuat aplikasi, indikator, dan tujuan. Gambar 2 merupakan storyboard tampilan menu pada bahan ajar, pada tampilan menu ada banyak button didalamnya yang terdiri dari permasalahan (No.3), materi (No.4), latihan (No.5) , kuis (No.6) dan tombol keluar dikanan atas. Sedangkan Gambar 3 merupakan storyboard pada tampilan permasalahan, ada button selanjutnya untuk pindah layout dan 
JURNAL GANTANG. September 2020; V(2): 191 - 201

p-ISSN. 2503-0671

e-ISSN. 2548-5547

menampilkan video maupun gambar yang sesuai dengan pertanyaan dari permasalahan yang dibuat khususnya pada materi Luas Permukaan Prisma.

Pada tahap pengembangan, dalam proses pembuatan produk yang dilakukan terlebih dahulu ialah desain yang sudah di buat oleh peneliti pada storyboard selanjutnya dikembangkan menjadi sebuah aplikasi dengan menggunakan sebuah software yaitu Android Studio dan menggunakan bantuan dari aplikasi lain seperti Powerpoint, Photoshop CS3, Paint, Camtasia, dan Filmora dalam pembuatan background, button, simbol, feedback, video, serta kuis yang berkaitan dengan materi prisma. Tampilan dari bahan ajar yang dibuat oleh peneliti diperlihatkan pada gambar 2, gambar 3 dan gambar 4.

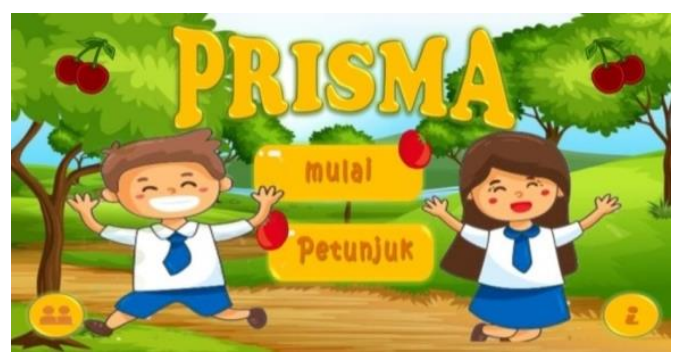

Gambar 2 Tampilan awal aplikasi

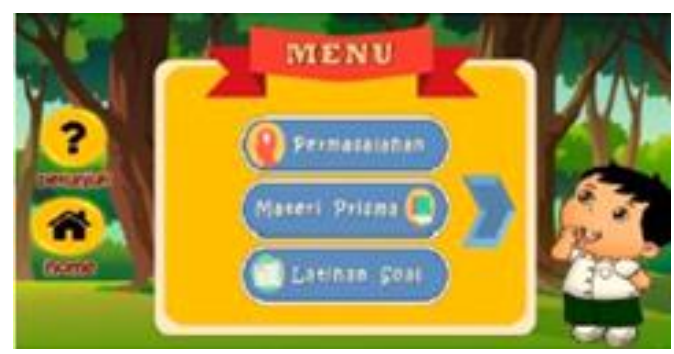

Gambar 3 Menu aplikasi

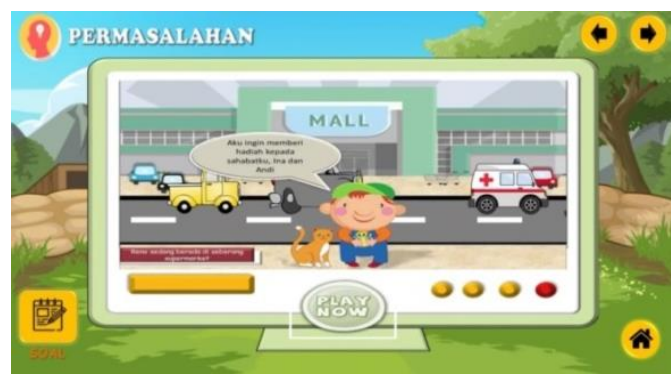

Gambar 4 Video permasalahan

Pada tahapan validasi ahli, peneliti menunjukkan aplikasi yang sudah peneliti buat

kepada para ahli dengan dilengkapi lembar validasi untuk diisi oleh para ahli sesuai dengan tanggapan mereka tentang aplikasi yang sudah digunakan. Validator pada penelitian ini ada 5 validator yang terdiri dari 3 validator materi (dua dosen FKIP Matematika Unsri dan satu guru matematika SMP Negeri 10 Palembang) dan 2 validator media (dua dosen FKIP Matematika Unsri). Adapun hasil validasinya yaitu berupa komentar dan saran dapat dilihat pada Tabel 1.

Tabel 1.

Hasil validasi ahli materi dan media

\begin{tabular}{|c|c|c|}
\hline No. & Nama Validator & Komentar/Saran \\
\hline 1 & $\begin{array}{l}\text { Scristia, S.Pd., M.Pd } \\
\text { (Ahli Materi, Dosen } \\
\text { Matematika FKIP } \\
\text { UNSRI) }\end{array}$ & $\begin{array}{l}\text { Perbaiki contoh } \\
\text { yang ada, sesuaikan } \\
\text { dengan fungsi benda } \\
\text { itu sendiri. Tidak } \\
\text { bisa dilihat secara } \\
\text { visualisai saja harus } \\
\text { sesuaikan dengan } \\
\text { fungsi konkret } \\
\text { tersebut }\end{array}$ \\
\hline 2 & $\begin{array}{l}\text { Jeri Araiku, S.Pd., } \\
\text { M.Pd (Ahli Materi, } \\
\text { Dosen Matematika } \\
\text { FKIP UNSRI) }\end{array}$ & $\begin{array}{l}\text { - Tujuan } \\
\text { pembelajaran lebih } \\
\text { komunikatif } \\
\text { - Sederhana button } \\
\text { - Tata letak button } \\
\text { diperbaiki } \\
\text { - Materi volume } \\
\text { prisma dihilangkan }\end{array}$ \\
\hline 3 & $\begin{array}{l}\text { Hj. Husmini, } \\
\text { (Ahli Materi, Guru } \\
\text { Matematika kelas } \\
\text { VIII SMP Negeri } 10 \\
\text { Palembang) }\end{array}$ & $\begin{array}{l}\text { Materinya } \\
\text { diperbanyak lagi }\end{array}$ \\
\hline 4 & \begin{tabular}{lr} 
Budi & \multicolumn{2}{r}{ Mulyono, } \\
S.Pd., M.Sc & (Ahli \\
Media, & Dosen \\
Matematika & FKIP \\
UNSRI) &
\end{tabular} & $\begin{array}{ll}\text { - Sudah cukup, layak } \\
\text { digunakan } & \text { untuk } \\
\text { penelitian } & \end{array}$ \\
\hline 5 & \begin{tabular}{lr}
\multicolumn{3}{l}{ Meryansumayeka, } \\
S.Pd., M.Sc & (Ahli \\
Media, & Dosen \\
Matematika & FKIP \\
UNSRI) &
\end{tabular} & 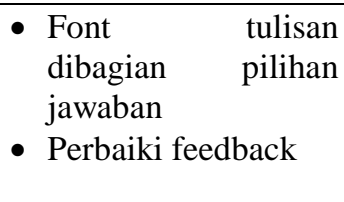 \\
\hline
\end{tabular}

Selain validasi bahan ajar kepada para ahli, peneliti juga melakukan uji coba one to-one kepada siswa. Sebelum dilakukannya uji coba pada tahap one-to-one, peneliti terlebih dahulu meminta rekomendasi dari guru mata pelajaran untuk mengusulkan tiga orang siswa dari kelas VIII dan tiga orang siswa dari kelas IX yang 
memiliki kemampuan dalam pelajaran matematika yang berbeda-beda yaitu dari kemampuan tinggi, sedang, dan rendah. Setelah didapatkan nama-nama siswa tersebut, peneliti langsung melakukan tahap one-to-one yang dilakukan di Laboratorium SMP Negeri 10 Palembang. Uji coba ini bertujuan untuk mendapatkan komentar dan saran dari siswa terhadap bahan ajar yang telah dikembangkan oleh peneliti. Berdasarkan hasil komentar dan saran siswa setelah menggunakan bahan ajar sebagian besar siswa memberikan komentar positif mengenai bahan ajar tersebut, akan tetapi ada siswa yang memberikan saran kepada peneliti baik dari segi font tulisan, materi pada bahan ajar, feedback, backsong, buttonya.

Perbaikan pada aplikasi yang sudah dibuat oleh peneliti berdasarkan saran maupun komentar dari validator merupakan hasil dari persetujuan dosen pembimbing mengenai perubahan-perubahan yang dilakukan oleh peneliti. Adapun hasil revisi yang sudah dilakukan oleh peneliti diperlihatkan pada gambar 5 , gambar 6, dan gambar 7 .

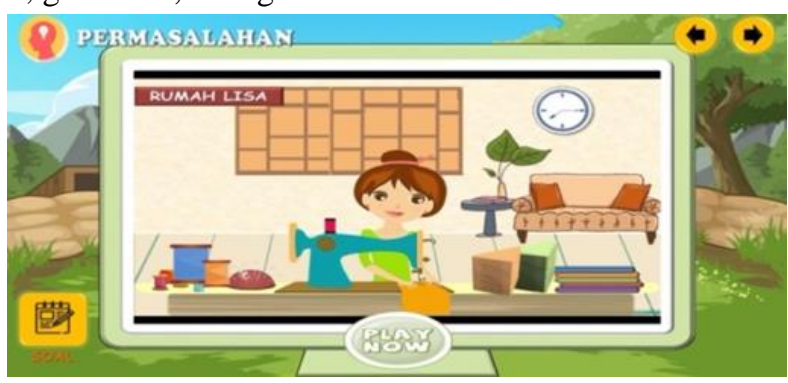

Gambar 5 Revisi video permasalahan

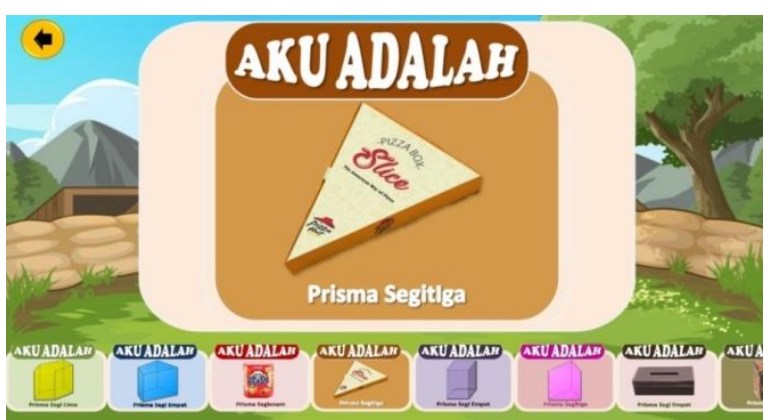

Gambar 6 Revisi contoh prisma

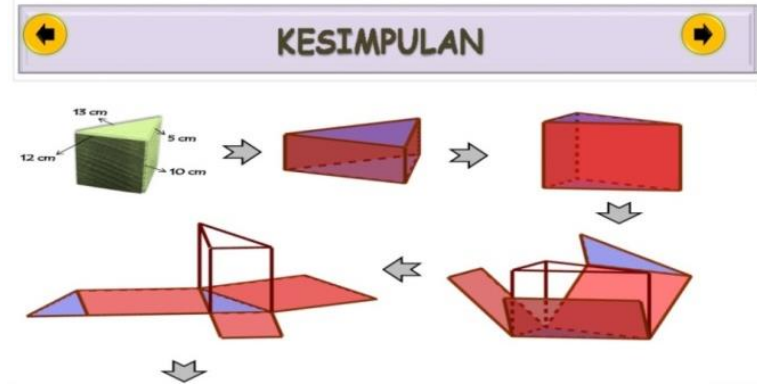

Gambar 7 Revisi kesimpulan permasalahan

Bahan ajar yang sudah direvisi oleh peneliti tersebut ditunjukkan kembali kepada validator. Para validator menyetujui revisi yang sudah dilakukan oleh peneliti dan menyatakan bahwa bahan ajar tersebut telah valid dengan menandatangani lembar surat pernyataan valid Tahap berikutnya yaitu small group untuk melihat kepraktisannya dari bahan ajar. Pada tahap small group terdapat dua kelompok yaitu kelompok kelas VIII dan kelas IX Pada uji coba small group didapatlah data observasi dan data angket, data observasi diperlihatkan pada tabel 2 .

Tabel 2.

Hasil observasi tahap small group

\begin{tabular}{clcc}
\hline No & \multicolumn{1}{c}{ Aspek yang diamati } & Persentase & Kategori \\
\hline 1 & $\begin{array}{l}\text { Siswa mudah dalam menggunakan } \\
\text { bahan ajar berbasis android. }\end{array}$ & $100 \%$ & $\begin{array}{l}\text { Sangat } \\
\text { setuju }\end{array}$ \\
\hline 2 & $\begin{array}{l}\text { Siswa termotivasi dalam } \\
\text { mengerjakan soal dalam bahan ajar } \\
\text { berbasis android. }\end{array}$ & $80 \%$ & Setuju \\
\hline 3 & $\begin{array}{l}\text { Materi dalam bahan ajar berbasis } \\
\text { android mudah dipahami oleh siswa. }\end{array}$ & $80 \%$ & Setuju \\
\hline 4 & $\begin{array}{l}\text { Bahan ajar berbasis android } \\
\text { membutuhkan waktu yang singkat } \\
\text { dalam penggunaannya. }\end{array}$ & $80 \%$ & Setuju \\
\hline 5 & $\begin{array}{l}\text { Siswa memiliki interaktivitas dalam } \\
\text { menggunakan bahan ajar berbasis } \\
\text { android. }\end{array}$ & $90 \%$ & $\begin{array}{c}\text { Sangat } \\
\text { Setuju }\end{array}$ \\
\hline Rata-rata & $86 \%$ & $\begin{array}{l}\text { Sangat } \\
\text { Praktis }\end{array}$ \\
\hline
\end{tabular}

Tabel 2 menunjukkan hasil observasi pada materi prisma sudah sangat praktis pada saat penggunaanya. Berikut tampilan aktivitas siswa saat uji coba small group diperlihatkan pada gambar 8 dan gambar 9 . 


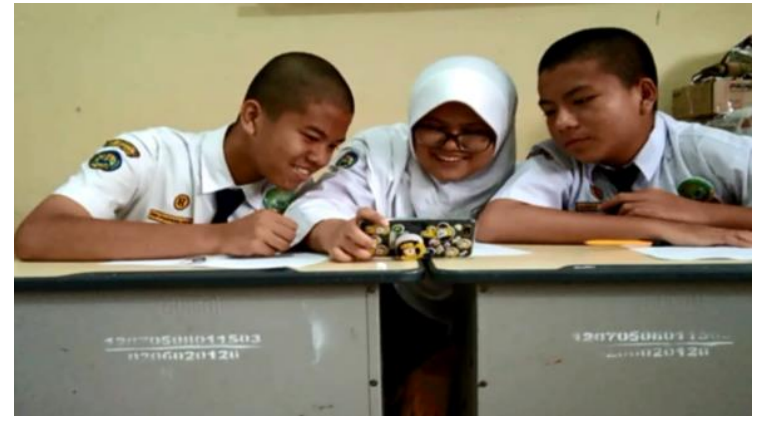

Gambar 8 Uji coba small group kelas VIII

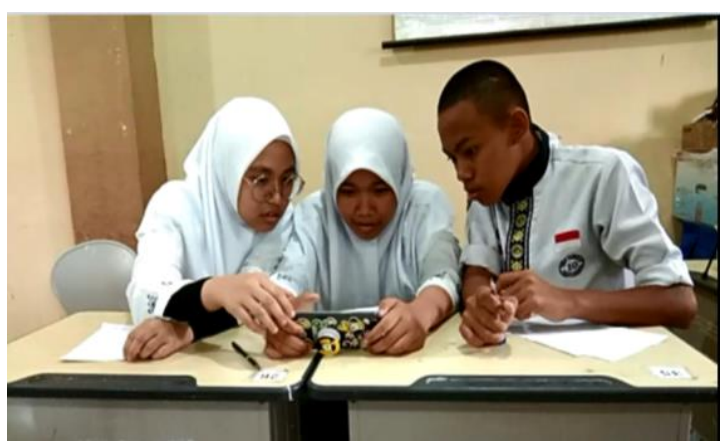

Gambar 9 Uji Coba small group kelas IX

Setelah selesai menggunakan bahan ajar yang sudah dibuat peneliti, selanjutnya siswa diberikan lembar angket yang berisikan pernyataan negatif maupun positif. Lembar angket tersebut haruslah diisi oleh siswa sesuai dengan tanggapan mereka masing-masing mengenai tanggapan siswa tentang bahan ajar yang sudah digunakan. Hasil dari lembar angket pada tahap small group terlihat pada tabel 3 selain itu ada pula komentar maupun saran yang siswa berikan terhadap bahan ajar.

Dari hasil persentase pada lembar angket di tahap small group didapatlah rata-rata hasil nya yaitu $86,33 \%$ yang terkategori sangat praktis sesuai dengan kriteria dari (Sugiyono, 2013: 135) yang menyatakan $84 \leq \mathrm{Na} \leq 100$ termasuk kedalam kategori sangat praktis. Adapun kriteria suatu bahan ajar dianggap praktis berdasarkan kriteria yang dikemukakan oleh Akker (1990) yang mana aspek praktis terpenuhi jika bahan ajar yang dikembangkan dapat digunakan, bahan ajar tersebut mudah digunakan, dan menarik atau tidaknya suatu bahan ajar dengan persentase yang berbeda-beda. Pada hasil yang didapatkan masih ada beberapa indikator yang belum mencapai nilai optimalnya yaitu $(100 \%)$ seperti pada indikator siswa merasa tidak ada kesulitan dalam dalam menggunakan bahan ajar 83,33\% setuju.

Tabel 3.

Hasil data angket small group

\begin{tabular}{|c|c|c|c|}
\hline No & Pernyataan & Persentase & Kategori \\
\hline 1 & $\begin{array}{l}\text { Siswa menjadi lebih bersemangat } \\
\text { dalam belajar matematika dengan } \\
\text { menggunakan bahan ajar berbasis } \\
\text { android. }\end{array}$ & $100 \%$ & Sangat Setuju \\
\hline 2 & $\begin{array}{l}\text { Siswa merasa tidak ada kesulitan } \\
\text { dalam menggunakan bahan ajar } \\
\text { berbasis android. }\end{array}$ & $70 \%$ & Setuju \\
\hline 3 & $\begin{array}{l}\text { Siswa menjadi lebih paham materi } \\
\text { yang diajarkan dengan } \\
\text { menggunakan bahan ajar berbasis } \\
\text { android. }\end{array}$ & $76,67 \%$ & Setuju \\
\hline 4 & $\begin{array}{l}\text { Siswa merasa tertarik untuk } \\
\text { belajar matematika menggunakan } \\
\text { bahan ajar berbasis android. }\end{array}$ & $93,33 \%$ & Sangat setuju \\
\hline 5 & $\begin{array}{l}\text { Siswa menjadi lebih senang belajar } \\
\text { materi prisma menggunakan bahan } \\
\text { ajar berbasis android. }\end{array}$ & $90 \%$ & Sangat Setuju \\
\hline 6 & $\begin{array}{l}\text { Siswa menjadi tidak malas belajar } \\
\text { materi prisma dengan } \\
\text { menggunakan bahan ajar berbasis } \\
\text { android }\end{array}$ & $93,33 \%$ & Sangat Setuju \\
\hline 7 & $\begin{array}{l}\text { Siswa menjawab permasalahan } \\
\text { dengan lebih baik setelah } \\
\text { menggunakan bahan ajar berbasis } \\
\text { android. }\end{array}$ & $73,33 \%$ & Setuju \\
\hline 8 & $\begin{array}{l}\text { Siswa menjadi menyukai belajar } \\
\text { matematika setelah menggunakan } \\
\text { bahan ajar berbasis android. }\end{array}$ & $90 \%$ & Sangat Setuju \\
\hline & $\begin{array}{l}\text { Siswa menjadi tidak bosan saat } \\
\text { belajar materi prisma dengan } \\
\text { menggunakan bahan ajar berbasis } \\
\text { android. }\end{array}$ & $93,33 \%$ & Sangat Setuju \\
\hline 10. & $\begin{array}{l}\text { Siswa menjadi tidak sulit } \\
\text { memahami materi yang ada dalam } \\
\text { bahan ajar berbasis android }\end{array}$ & $83,33 \%$ & Setuju \\
\hline Rat & -rata: & $86,33 \%$ & $\begin{array}{l}\text { Sangat } \\
\text { Praktis }\end{array}$ \\
\hline
\end{tabular}

Pada indikator siswa menjadi lebih paham materi $76 \%$ setuju, hal tersebut didapatkan karena ada beberapa siswa yang menjawab ragu-ragu. Ketika menggunakan bahan ajar secara bersama-sama dengan kognitif siswa yang berbeda-beda tentunya bisa membuat siswa yang lama menalar dan pahamnya menjadi kebingungan ketika temannya yang lain sudah lanjut ke tampilan berikutnya. Untuk persentase siswa tertarik dalam belajar 93,33\% sangat setuju, hal ini terjadi karena ada beberapa siswa menjawab setuju saja sehingga untuk perhitungannya hampir mencapai $100 \%$ dan terlihat pada saat siswa mengoperasikan bahan ajarnya dengan rasa penasaran ingin langsung membuka aplikasi yang diberikan peneliti.

Persentasi pada pertanyaan siswa menjadi lebih senang belajar $90 \%$ sangat setuju, 
hal ini terjadi karena pada saat siswa mengoperasikan bersama bahan ajarnya siswa menjadi senang terlihat pada saat mereka menjawab jawaban yang benar lalu muncul feedback dengan diiringi suara animasi sehingga membuat mereka senang, hasil ini sesuai dengan pendapat Arsyad (2011:15) yang menyatakan bahwa adanya bahan ajar yang menarik dapat membangkitkan motivasi belajar siswa dan membawa pengaruh-pengaruh psikologis terhadap siswa. Namun persentasenya tak sampai nilai optimal karena ada siswa yang mencentang setuju saja. Pada poin siswa tidak malas belajar persentasenya $93,33 \%$ sangat setuju, hal ini terjadi karena siswa merasa semangat saat belajarnya terlihat pada saat siswa mengoperasikan bahan ajar dengan sungguhsungguh dan ingin tau isi dari bahan ajar tersebut, namun untuk perhitungannya tidak sampai $100 \%$ karena ada siswa yang mencentang setuju saja pada lembar angketnya.

Persentase pada indikator siswa menjawab permasalahan dengan baik yaitu $73,33 \%$ setuju, hal ini dapat terjadi karena siswa merasa belum optimal dalam menjawab soal pada kuis yang terbatas oleh waktu yang sedikit dan begitu cepat sehingga banyak siswa mencentang ragu-ragu pada indikator ini. Pada indikator siswa menyukai belajar matematika dengan android dan siswa menjadi tidak bosan belajar dengan persentase $90 \%$ sangat setuju dan 93,33\% sangat setuju, hal ini terlihat pada proses siswa menggunakan bahan ajarnya menjadi lebih aktif saat melihat tampilan dan animasi yang disugguhkan dalam bahan ajar. Untuk perhitungannya tidak sampai $100 \%$ karena ada siswa yang mencentang ragu-ragu dan setuju pada indikator tersebut. Pada indikator siswa menjadi tidak sulit memahami materi yang ada dalam bahan ajar persentasenya $83,33 \%$ setuju, hal ini dapat terjadi karena ada salah satu siswa yang mencentang ragu-ragu pada indikator ini dan berpendapat bahwa ada tampilan tertentu yang terlalu banyak tulisan sehingga membuat dia bingung dalam memahami materinya sedangkan untuk siswa lainnya mencentang setuju dan sangat setuju. Namun ada salah satu indikator yang persentasenya $100 \%$ yaitu pada indikator siswa menjadi lebih bersemangat dalam belajar matematika, hal ini terjadi karena saat siswa diberikan bahan ajar berbasis android siswa menjadi penasaran dan antusias saat menggunakannya, dan hasil tersebut diperole dari perhitungan angket yang mana pada angket semua siswa mencentang sangat setuju hasil ini sejalan dengan pendapat dari Munir (2013) bahwa penggunaan bahan ajar yang menarik dapat meningkatkan minat belajar siswa serta memotivasi siswa untuk belajar. Setelah dilakukannya small group, maka tahapan selanjutnya ialah merevisi kembali bagianbagian yang menjadi komentar dari tiap siswa. Dari kedua tahapannya ini maka bahan ajar yang sudah peneliti buat sudah terkategori valid dan praktis.

Hasil penelitian tersebut diperkuat oleh beberapa penelitian sebelumnya seperti penelitian yang dilakukan oleh Wahyuni (2018) menunjukkan bahwa adanya penggunaan android dalam pembelajaran dapat meningkatkan minat siswa dalam belajar karena muncul rasa senang dan tertarik dalam menggunaan aplikasi saat belajar hal ini terlihat pada persentase data angket respon siswa yaitu ketertarikan $90 \%$, rasa senang $87,5 \%$ yang terkategori sangat tinggi, lalu pada penelitian yang dilakukan oleh Fandi (2016) menunjukkan hasil persentase respon siswa terhadap bahan ajar yaitu senang $90,28 \%$, tertarik $84,72 \%$, mudah dalam penggunaannya $83,33 \%$ sedangkan pada penelitian ini hasil data angket menunjukkan ketertarikan 93,33\%, lebih senang $90 \%$, lebih bersemangat $100 \%$, dan mudah menggunakannya $83,33 \%$. Hasil ini sejalan dengan pendapat dari Arsyad (2011: 15) yang menyatakan bahwa pemakaian bahan ajar yang menarik dalam proses belajar dapat membangkitkan motivasi dan membawa pengaruh priskologis pada siswa serta mudah dalam penggunaannya karena android mudah diakses sama siapa saja dan dimana saja (Azizah, 2017). 


\section{JURNAL GANTANG. September 2020; V(2): 191 - 201 \\ p-ISSN. 2503-0671 \\ e-ISSN. 2548-5547}

\section{Kesimpulan}

Berdasarkan penelitian yang telah dilakukan, maka dapat disimpulkan bahwa bahan ajar berbasis android materi prisma untuk pembelajaran berbasis masalah dikelas VIII sudah dikategorikan valid dan praktis. Bahan ajar yang dibuat oleh peneliti yaitu berbentuk sebuah aplikasi yang bisa digunakan di smartphone baik siswa maupun guru di sekolah.

\section{Referensi}

Akker, J. V. (1999). Design approaches and tools in education and training chapter 1: principles and methods of development research. Dordrecht: Kluwer Acdemic Publisher.

Allo, D. P., et al. (2019). Penerapan model pembelajaran problem based learning setting kelompok untuk meningkatkan kemampuan pemecahan masalah matematis siswa di SMP Swasta Antam Pomalaa. Jurnal Pendidikan Matematika 10(1), 19-30.

Azizah, F.R., Sujadi, I., \& Chrisnawati, H.E.. (2018). Penerapan problem based learning pada materi luas permukaan serta volume prisma dan limas ditinjau dari kemandirian belajar siswa kelas VIII SMP Negeri 2 Banyudono. Jurnal Pendidikan Matematika dan Matematika Solusi, 2(4), 298 - 306.

Hardiyanti, E. A. (2018). Penerapan model pembelajaran berbasis masalah untuk meningkatkan hasil belajar siswa kelas VII C MTSN 1 Kotapalu dalam menyelesaikan soal cerita keliling dan luas daerah persegi panjang. Jurnal Elektronik Pendidikan Matematika Tadulako, 5(3), 343-354

Jazuli, M., Azizah, L. F., \& Melta, N. M. (2017). Pengembangan bahan ajar elektronik berbasis android sebagai media interaktif. Lensa: Jurnal Pendidikan IPA, 7(2), 47-65. https://doi.org/10.24929/lensa.v7i2.22

Kasmawati. (2017). Penerapan kerangka pembelajaran problem based learning materi bangun ruang sisi datar untuk siswa kelas VIII SMP. . (Unpublished master's thesis). Universitas Terbuka, Jakarta.

Kemendikbud. (2019). Materi pelajaran ujian nasional smp negeri. retrieved from kementrian pendidikan dan budaya: https://un.kemdikbud.go.id/

Mahmidatul. (2020). Pengembangan perangkat pembelajaran matematika terintegrasi keterampilan abad 21 melalui penerapan model problem based learning. Jurnal Gantang, $\quad V(1), \quad 69-76$. https://doi/org/10.31629/jg.v5i1.1609

Manasikana, A. L. (2017). Pengembangan bahan ajar interaktif berbasis android pada materi jurnal penyesuaian dan jurnal koreksi untuk kelas XII akuntansi di SMKN 1 Surabaya. Jurnal Pendidikan Akuntansi,5(2), 1-8

Munir. (2012). Multimedia konsep dan aplikasi dalam pendidikan. bandung: Alfabeta.

Muyaroah, S. \& Fajartia, M. (2017). Pengembangan media pembelajaran berbasis android dengan menggunakan aplikasi adobe flash CS 6 pada mata pelajaran biologi. Innovative Journal of Curriculum and Education Techonlogy, 6(2), 79-83. doi: 10.15294/IJCET.V6I2.19336

Prisiska R, H. \& Hapizah (2017). Pengembangan LKS berbasis problem based learning materi aritmatika sosial kelas VII. JPPM, 10(2), 82-94

Purnama, R.B., Feriansyah S., Chandra E. (2017). Pengembangan media pembelajaran mobile learning berbasis android sebagai suplemen pembelajaran fisika SMA pada materi usaha dan energi. Jurnal Pembelajaran Fisika, 5(4), 63-74

Rusman, D. (2017). Belajar dan pembelajaran berorientasi standar proses pendidikan. Jakarta: Prenada Media.

Sanjaya, W. (2011). Strategi pembelajaran berorientasi standar proses pendidikan. Jakarta: Kencana.

Sondek, N. (2016). Penerapan model pembelajaran kooperatif tipe think pair share untuk meningkatkan hasil belajar 
siswa pada materi luas permukaan dan volume prisma di kelas VIII SMP Negeri 18 Palu. Jurnal Elektronik Pendidikan Matematika Tadulako, 4(2). 208-220

Sugiyono, D. (2013). Metode penelitian pendidikan penelitian kuantitatif, kualitatif, dan $R \& D$. Bandung: Alfabeta.

Sunarto, N. D. (2015). Pengembangan multimedia interaktif berbasis android pada materi senyawa hidrokarbon sebagai media pembelajaran kimia SMA/Ma Kelas X. (Unpublished skripsi). Universitas Negeri Yogyakarta, Yogyakarta.

Tan, O. (2003). Problem based learning innovation. Singapore: Cengage Learning.

Wahyuni, S. (2018). Pengaruh model pembelajaran problem based learning terhadap kemampuan pemecahan masalah matematika siswa di kelas VIII SMP IT Annur Prima Medan. (Unpublished Skripsi). Universitas Islam Negeri Sumatera Utara, Medan.

Wijani, N. A. (2013). Desain pembelajaran pendidikan: tata rancangan pembelajaran menuju pencapaian kompetensi. Yogyakarta: Ar-Ruzz Media.

Wijayanto, Y. Y. (2018). Mudah membuat dan berbisnis aplikasi android dengan android studio. Jakarta: PT. Elex Media Komputindo.

Yamin, M. (2013). Strategi \& metode dalam model pembelajaran. Jakarta: GP Press Group.

Yetizon, Tusa'diah, R. (2020). Pengembangan perangkat pembelajaran berbabis model pembelajaran discovery learning pada materi matematika berorientasi mitigasi bencana. Jurnal Gantang V (1) , 69-76. https://doi.org/10.31629/jg.v5i1.1898 
JURNAL GANTANG. September 2020; V(2): 191 - 201

p-ISSN. 2503-0671

e-ISSN. 2548-5547 